\title{
Sputter deposited bioceramic coatings: surface characterisation and initial protein adsorption studies using surface-MALDI-MS
}

\author{
A. R. Boyd • G. A. Burke • H. Duffy • \\ M. Holmberg • C. O' Kane • B. J. Meenan • \\ P. Kingshott
}

Received: 30 December 2009/Accepted: 25 October 2010/Published online: 21 November 2010

(C) Springer Science+Business Media, LLC 2010

\begin{abstract}
Protein adsorption onto calcium phosphate $(\mathrm{Ca}-\mathrm{P})$ bioceramics utilised in hard tissue implant applications has been highlighted as one of the key events that influences the subsequent biological response, in vivo. This work reports on the use of surface-matrix assisted laser desorption ionisation mass spectrometry (Surface-MALDIMS) as a technique for the direct detection of foetal bovine serum (FBS) proteins adsorbed to hybrid calcium phosphate/titanium dioxide surfaces produced by a novel radio frequency (RF) magnetron sputtering method incorporating in situ annealing between $500^{\circ} \mathrm{C}$ and $700^{\circ} \mathrm{C}$ during deposition. XRD and XPS analysis indicated that the coatings produced at $700^{\circ} \mathrm{C}$ were hybrid in nature, with the presence of $\mathrm{Ca}-\mathrm{P}$ and titanium dioxide clearly observed in the outer surface layer. In addition to this, the $\mathrm{Ca} / \mathrm{P}$ ratio was seen to increase with increasing annealing temperature, with values of between 2.0 and 2.26 obtained for the $700^{\circ} \mathrm{C}$ samples. After exposure to FBS solution, surface-MALDI-MS indicated that there were significant differences in the protein patterns as shown by unique peaks detected at
\end{abstract}

\footnotetext{
A. R. Boyd ( $ه)$ - G. A. Burke · H. Duffy · C. O’ Kane · B. J. Meenan

Nanotechnology and Integrated Bioengineering Centre (NIBEC), University of Ulster at Jordanstown, Shore Road,

Newtownabbey, Co, Antrim BT37 0QB, Northern Ireland (UK)

e-mail: ar.boyd@ulster.ac.uk

M. Holmberg

Department of Micro- and Nanotechnology, Technical

University of Denmark, Frederiksborgvej 399, Build. 124,

PO 49, 4000 Roskilde, Denmark

P. Kingshott

Faculty of Science, The Interdisciplinary Nanoscience Centre (iNANO), University of Aarhus, Ny Munkegade, Build. 1521, 8000 Aarhus C, Denmark
}

masses below $23.1 \mathrm{kDa}$ for the different surfaces. These adsorbates were assigned to a combination of growth factors and lipoproteins present in serum. From the data obtained here it is evident that surface-MALDI-MS has significant utility as a tool for studying the dynamic nature of protein adsorption onto the surfaces of bioceramic coatings, which most likely plays a significant role in subsequent bioactivity of the materials.

\section{Introduction}

There is a great deal of interest in enhancing the surface properties of calcium phosphate (Ca-P) bioceramic coatings on hard tissue implant devices in order to increase their performance in vivo. Of the many techniques available, radio frequency (RF) magnetron sputtering has been identified as a particularly useful technique for the deposition of such Ca-P thin films due to the ability of the technique to provide greater control of the coating's properties and improved adhesion between the substrate and the coating [1-14]. More recently, the addition of titanium dioxide $\left(\mathrm{TiO}_{2}\right)$ into $\mathrm{Ca}-\mathrm{P}$ coatings in order to create hybrid surfaces has been recognised as a key route for enhancing their stability and providing the appropriate biofunctionality [15-23].

Numerous reports have highlighted the importance of protein adsorption to hydroxyapatite (HA) [24-30] and $\mathrm{TiO}_{2}$ [31-34] surfaces in relation to cell growth (attachment, spreading and differentiation) on hard tissue implants. In particular, the role played by the individual cell-adhesion serum proteins fibronectin and vitronectin in initial attachment and spreading of cells [35]. Despite these important findings the precise mechanisms of protein adsorption and subsequent cell attachment and growth are 
still very poorly understood. One possible reason for this is the complex nature of biological media like serum that biomaterials are exposed to and the potential for involvement of numerous other proteins co-adsorbing to surfaces, potentially providing additional signals to attaching cells. In human serum so far over 3,000 proteins have been identified using classical proteomics approaches [36], and it is a "mind boggling" thought that an estimated 50,000 molecular forms of the plasma proteins could actually exist at any given time [37]. Foetal bovine serum (FBS), often used as a cell culture medium, is even less "well characterised". One recent report identified 91 proteins including several growth factors in FBS [38], with many of the species also found in human serum.

Studying protein adsorption is also an additional complicating factor in biomaterials research. Despite numerous methods being able to provide reliable quantitative data on the adsorption of individual proteins adsorbed from single solutions or from complex mixtures [39], new methods need to be developed firstly to detect and secondly to identify key components adsorbing from protein solutions like serum. Matrix Assisted Laser Desorption Ionisation Time-of-Flight Mass Spectrometry (MALDI-ToF-MS) is an established method for detecting protein analytes in solution at very low concentrations [40]. In conventional MALDI-ToF-MS the protein is dissolved in a solution together with photoactive molecules (e.g. trans-3,5-dimethoxy-4-hydroxy cinnamic acid/sinapinic acid). This mixture is applied onto a sample stub and the solvent evaporated to yield "photomatrix" crystals with encapsulated protein molecules. Under ultra-high vacuum conditions the crystals are irradiated with a pulsed UV laser causing ablation. Proteins are ionised in the expanding plume as a result of complex photochemical reactions [41] and are extracted by an electrical potential before travelling down the ToF flight tube to the detector. An adaptation of the method is the so-called surface-MALDI technique [42, 43]. After the protein adsorption experiment, and thorough rinsing to remove loosely attached proteins, droplets of the matrix solution are applied directly to the protein coated surface. The solution consists of an organic solvent (e.g. acetonitrile) and has a low $\mathrm{pH}$, conditions that are suitable for desorbing a substantial amount of the adsorbed protein. After solvent evaporation matrix crystals are formed in the conventional way with encapsulated proteins, and the sample is glued to the MALDI sample plate for analysis in the conventional way.

Our approach is to utilise surface-MALDI in an attempt to detect and identify some of the proteins that adsorb to the calcium phosphate/titanium dioxide hybrid coatings surfaces from FBS solution. The experiments are aimed at mimicking cell adhesion experiments to the hybrid coatings, in which osteoblasts are suspended in 10\% FBS during cell culture [22]. In doing so we aim to detect proteins that are common adsorbates to most modified surfaces, and whose function in cellular responses may well be unknown. The work provides a starting point for taking a surface proteomics-like approach to understanding biocompatibility of hard tissue implants by firstly identifying key protein adsorbates.

\section{Materials and methods}

\subsection{Sputtering procedure}

For this study, titanium was sputter deposited onto abraded Ti-6Al-4V substrates. Subsequently, Ca-P coatings were deposited onto these polycrystalline titanium layers and thermally annealed, in situ. All details of the deposition and thermal processing conditions employed to create the $\mathrm{Ca}-\mathrm{P} / \mathrm{TiO}_{2}$ hybrid surfaces are given below.

Titanium layers were sputter deposited onto abraded Ti-6Al-4V substrates (Titanium International Ltd.) $(20 \mathrm{~mm} \times 20 \mathrm{~mm} \times 0.5 \mathrm{~mm})$ from two titanium metal targets ((99.995\%) Kurt J. Lesker Ltd, USA) of $76 \mathrm{~mm}$ diameter and $3.2 \mathrm{~mm}$ thickness. The targets were mounted at $45^{\circ}$ to the substrate surface. The break-in procedure prior to deposition was conducted at a ramp rate of $15 \mathrm{~W} / \mathrm{min}$ (all with the source shutter closed). The base pressure was below $7 \times 10^{-5} \mathrm{~Pa}$, with an argon gas flow rate (BOC, $99.995 \%$ ) of between 15 and 20 standard cubic centimetres per minute $(\mathrm{sccm})$ at a chamber pressure of 2.0 Pascals $(\mathrm{Pa})$ and a throw distance of $100 \mathrm{~mm}$. The deposition was performed at $200 \mathrm{~W}$ for $1 \mathrm{~h}$ under the same atmospheric conditions as were used for the target break-in procedure. The approximate power density for the titanium targets was $8.7 \mathrm{~W} \mathrm{~cm}^{-2}$.

Hydroxyapatite (HA) targets, $76 \mathrm{~mm}$ in diameter and $5 \mathrm{~mm}$ thick were produced by dry pressing HA powder (Merck KGaA, Darmstadt, Germany) at a load of $40 \mathrm{kN}$ for $10 \mathrm{~min}$ with a loading rate of $10 \mathrm{kN} / \mathrm{min}$. Radio Frequency (RF) magnetron sputtering was performed using a cluster of three high vacuum Torus $3 \mathrm{M}$ sputtering sources in a custom designed system (Kurt J. Lesker Ltd, USA) each operating with a $13.56 \mathrm{MHz}$ RF generator and an impedance matching network (Huettinger, GmbH, Germany). The sources were all mounted at $45^{\circ}$ to the substrate surface. For deposition from the HA targets onto the titanium layers, the RF power in the sputtering system was ramped up slowly to provide an initial break-in phase, thereby minimising any thermal shock effects. The break-in prior to deposition from the HA target was conducted at a ramp rate of 5 Watts (W) per minute (all with the source shutter closed). The base pressure was below $7 \times 10^{-5} \mathrm{~Pa}$, with an argon gas flow rate (BOC, 99.995\%) of between 15 and 18 
sccm at a chamber pressure of 2.0 Pascals $(\mathrm{Pa})$ and a throw distance of $100 \mathrm{~mm}$. The fragility of the HA targets limited their power absorption capacity and consequently deposition was performed at $150 \mathrm{~W}$ for $5 \mathrm{~h}$ under the same atmospheric conditions as were used for the target break-in procedure. The power density for these HA targets was approximately $3.3 \mathrm{~W} \mathrm{~cm}^{-2}$.

In situ annealing was performed on the coatings during sputter deposition. Heating was conducted using an array of quartz lamps mounted immediately behind the substrates in the sputtering system. The coatings were subjected to a ramp rate of $5^{\circ} \mathrm{C} / \mathrm{min}$ to the processing temperature (with the source shutters closed). in situ annealed was then performed throughout the duration of the deposition cycle for the Ca-P coating $(5 \mathrm{~h})$. After deposition of the Ca-P coating the source shutters were closed and the coatings were subjected to a ramp rate of $5^{\circ} \mathrm{C} / \mathrm{min}$ back down to a temperature of less than $30^{\circ} \mathrm{C}$ before they were removed for characterisation. Coatings were produced at 500, 600 and $700^{\circ} \mathrm{C}$ for this study.

\subsection{Characterisation of the $\mathrm{Ca}-\mathrm{P} / \mathrm{TiO}_{2}$ coatings}

X-Ray diffraction (XRD) of the samples were carried using a Bruker D8 Discover Diffractometer fitted with a Gobel Mirror. A Cu K $\alpha$ X-ray radiation $(\lambda=1.540 \AA$ ) source was employed with diffraction scans obtained at a tube voltage of $40 \mathrm{kV}$ and a tube current of $40 \mathrm{~mA}$. Each diffraction scan was recorded at $2 \theta$ values from 20 to $50^{\circ}$ with a step size of $0.04^{\circ}$ and a scan dwell time for each increment of $30 \mathrm{~s}$. For the grazing incidence angle XRD studies of $\mathrm{Ca}-\mathrm{P} / \mathrm{TiO}_{2}$ coatings on the Ti-6Al-4V substrates the tube angle was set to $0.75^{\circ}$.

X-ray photoelectron spectroscopy (XPS) of the samples were carried out using a Kratos Axis Ultra DLD spectrometer. Spectra were recorded by employing monochromated $\mathrm{Al}_{\mathrm{K} \alpha} \mathrm{X}$-rays $(\mathrm{h} v=1,486.6$ electron volts $(\mathrm{eV}))$ operating at $15 \mathrm{kV}$ and $15 \mathrm{~mA}(225 \mathrm{~W})$. A hybrid lens mode was employed during analysis (electrostatic and magnetic), with an analysis area of approximately $300 \mu \mathrm{m}$ $\times 700 \mu \mathrm{m}$. For each sample, take off angles (TOAs) of $0^{\circ}$, $45^{\circ}$ and $75^{\circ}$ (with respect to the sample surface) were employed. Wide energy survey scans (WESS) were obtained over the range $0-1,200 \mathrm{eV}$ binding energy (BE) at a pass energy of $160 \mathrm{eV}$. High resolution spectra were recorded for C1s (280-303 eV), O1s (524-543 eV), Ca2p (342-357 eV), Ti2p (448-469 eV) and P2p (126-141 eV) at a pass energy of $20 \mathrm{eV}$. The Kratos charge neutraliser system was used on all samples. Sample charging effects on the measured $\mathrm{BE}$ positions were corrected by setting the lowest $\mathrm{BE}$ component of the $\mathrm{C} 1 \mathrm{~s}$ spectral envelope to $285.0 \mathrm{eV}$, i.e. the value generally accepted for adventitious carbon surface contamination [44]. Peak fitting of the high-resolution spectral regions was performed by subtraction of a linear background and application of a mixed Gaussian-Lorentzian synthetic peak. Full width at half-maximum (FWHM) values for each component were in the range 1.4-1.6 eV and other parameters were applied as part of the instrument-specific curve-fitting routine.

The surface topography of the samples were evaluated using a Digital Instruments Dimension 3000 Scanning Probe Microscope (SPM). The surface was scanned in tapping mode over $5 \mu \mathrm{m} \times 5 \mu \mathrm{m}$ and $10 \mu \mathrm{m} \times 10 \mu \mathrm{m}$ areas using a force modulated etched silicon probe (FESP) with a nominal force constant of $0.28 \mathrm{~N} \mathrm{~m}^{-1}$. In tapping mode a high frequency $(75 \mathrm{kHz}) \mathrm{z}$-oscillation is imposed upon the probe during $x-y$ raster scanning, which only allows intermittent contact between the probe and the sample surface. This eliminates shear forces because the probe is not in constant contact with the sample. The images were collected and subjected to minimal computational manipulation, allowing only for a tilt removal.

The coating thickness of the titanium layers and the $\mathrm{Ca}-\mathrm{P}$ coatings were determined using a Dektak 8 stylus profilometer (Veeco Instruments Inc, USA). Measurements were taken across 10 step height positions on each sample created by masking the Ti-6Al-4V substrates with aluminium foil prior to deposition in the sputtering system. A $12.5 \mu \mathrm{m}$ diameter diamond tipped stylus was employed with scans lengths of $1,000 \mu \mathrm{m}$ at a force of $15 \mathrm{mg}$.

\subsection{Protein adsorption studies using surface-MALDI-MS}

The detection of proteins adsorbed to the calcium phosphate/titanium dioxide coatings exposed to $10 \%$ foetal bovine serum (Cambrex, FBS) was undertaken using MALDI-ToF-MS in surface mode (surface-MALDI). The principles of this method have previously been described $[42,43]$. In brief, protein adsorption was performed by exposing the surfaces to a $10 \%$ solution of heat treated FBS for $1 \mathrm{~h}$ at $37^{\circ} \mathrm{C}$. The samples were then rinsed three times in MilliQ water and left to air dry. Immediately after drying the top surface of the sample was coated with enough methanol to wet the entire surface (typically $100 \mu \mathrm{l}$ ). After the methanol evaporated, 4-5 droplets of matrix solution $(0.5$ or $1 \mu \mathrm{l})$ were applied and the samples left to air dry immediately. The matrix is a saturated solution of sinapinic acid (Fluka) in 1:1 acetonitrile (Fisher Scientific): 0.1\% trifluoroacetic acid (TFA, Sigma-Aldrich). The samples were fixed to the MALDI sample plate using double-sided sticky tape (Scotch) and inserted into the instrument.

MALDI-ToF-MS was performed using a Bruker Reflex IV MALDI-ToF mass spectrometer (Bruker-Franzen Analytik, Germany). The instrument uses a pulsed UV laser $\left(\mathrm{N}_{2}, 337 \mathrm{~nm}, 3 \mathrm{~ns}\right.$ pulse-width) for protein ionization 
and delayed extraction combined with time-of-flight analysis for mass separation. Linear detection was employed with a post-acceleration of $10 \mathrm{keV}$ for improved sensitivity. For the surface-MALDI experiments the laser power was adjusted to approximately $80 \%$ of its maximum for maximum ion yields and, and the spectra presented are the sum of 1,000 shots. External calibration was performed using a bovine serum albumin standard with three point calibration on the $[\mathrm{M}+\mathrm{H}]^{+},[2 \mathrm{M}+\mathrm{H}]^{+}$and $[\mathrm{M}+2 \mathrm{H}]^{2+}$ ions. All MALDI-MS experiments were performed in duplicate.

\section{Results and discussion}

\subsection{Stylus profilometry}

The coating thickness of the titanium layers on the Ti-6Al$4 \mathrm{~V}$ substrates, as determined by stylus profilometry was $533 \pm 43 \mathrm{~nm}$. The coating thickness of the $\mathrm{Ca}-\mathrm{P}$ coatings was $320 \pm 34 \mathrm{~nm}$.

\section{$3.2 \mathrm{XRD}$}

The XRD patterns for the Ti-6Al-4V substrate, the sputter deposited titanium interlayer and the as-deposited $\mathrm{Ca}-\mathrm{P}$ coating on the titanium interlayer were reported previously [23]. Upon in situ annealing of the $\mathrm{Ca}-\mathrm{P}$ coating on the titanium layer to $500^{\circ} \mathrm{C}$, the XRD data clearly indicates the presence of HA, as shown in Fig. 1a. Peaks that are clearly indicative of HA were seen throughout the pattern with $2 \theta$ values that correspond closely to those observed in the ICDD file \#09-0432 for HA. The four strongest peaks are observed at 25.9, 31.7, 32.1 and $32.8^{\circ} 2 \theta$, and correspond to $002,210,211$ and 112 reflections, respectively. Furthermore, the intensity of the 002 reflection at $25.9^{\circ} 2 \theta$

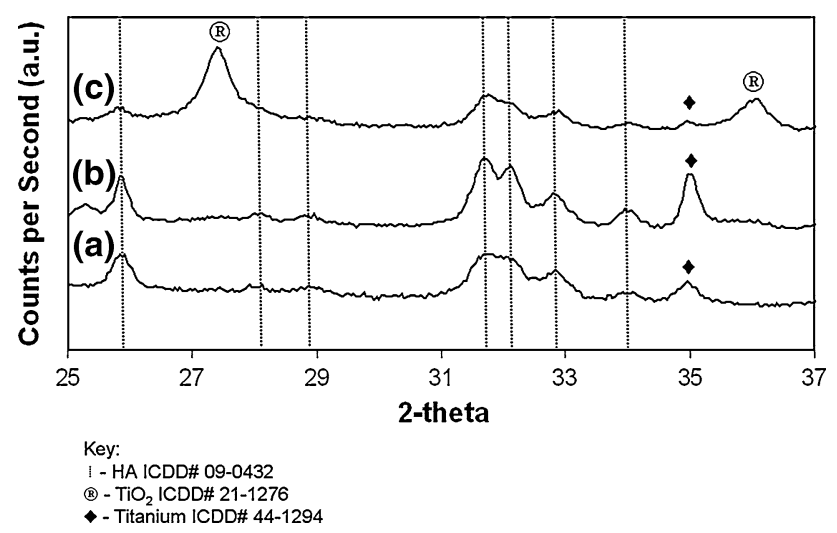

Fig. 1 XRD patterns for $\mathrm{Ca}-\mathrm{P}$ coatings on titanium layers where (a) ISA $500^{\circ} \mathrm{C},(b)$ ISA $600^{\circ} \mathrm{C}$ and (c) ISA $700^{\circ} \mathrm{C}$ samples (ISA-in situ annealed) shows that this coating has a 002 preferred orientation, typical of coatings deposited under the conditions employed here $[45,46]$. Peaks indicative of the underlying titanium layer are also observed at $2 \theta$ values similar to those for titanium layer and correspond closely to those observed for the ICDD file \#44-1294 for titanium. The XRD pattern for the $\mathrm{Ca}-\mathrm{P}$ coating in situ annealed to $600^{\circ} \mathrm{C}$, as shown in Fig. $1 \mathrm{~b}$, also has peaks associated with HA (ICDD file \#09-0432 for HA), however, these peaks show enhanced resolution when compared to the in situ annealed $500^{\circ} \mathrm{C}$ coatings. Peaks from the underlying titanium are also observed at similar positions to those observed for the coating at $500^{\circ} \mathrm{C}$. It is noticeable that no rutile was detected in the sample in situ annealed to $600^{\circ} \mathrm{C}$ when compared to those produced by post deposition annealing to the same temperature in earlier work [22, 23]. This difference is most likely a direct consequence that post deposition annealing in previous studies was performed in air, whereas the in situ annealing of the samples here was performed under an argon gas pressure of $2 \mathrm{~Pa}$ during sputter deposition. It is therefore suggested that the formation of titanium dioxide and its subsequent diffusion through the $\mathrm{Ca}-\mathrm{P}$ outer layer is diminished during in situ annealed due to the lack of available oxygen species throughout the vacuum deposition process. Whenever these coatings are in situ annealed to $700^{\circ} \mathrm{C}$, significant changes are observed when against the in situ annealed surfaces at 500 and $600^{\circ} \mathrm{C}$. Peaks indicative of HA (ICDD file \#090432) and titanium (ICDD file \#44-1294) are observed, as shown in Fig. 1c. In addition to these, peaks corresponding to rutile $\mathrm{TiO}_{2}$ are also evident at 27.4 and $35.9^{\circ} 2 \theta$, and correspond closely to peaks observed in the ICDD file \#211276 for rutile $\mathrm{TiO}_{2}$. The titanium layer of the $700^{\circ} \mathrm{C}$ in situ annealed coatings has oxidised and diffused through the HA layer more readily than the surfaces that were in situ annealed at 500 and $600^{\circ} \mathrm{C}$.

\subsection{XPS}

The XPS data for the uppermost surface of the Ti-6Al-4V substrate, the sputter deposited titanium interlayer (at a Take Off Angle (TOA) of $0^{\circ}$ ) and the as-deposited $\mathrm{Ca}-\mathrm{P}$ coating have been reported previously [23]. Furthermore, the as-deposited coating was not analysed at different TOAs due to the fact it would not be utilised in any of the MALDI-MS experiments. From previous experience these coatings showed a distinct lack of stability in physiological fluid and were not stable enough to conduct such experiments [10]. The XPS survey scan for the Ca-P coating on the titanium layer in situ annealed to $500^{\circ} \mathrm{C}\left(0^{\circ} \mathrm{TOA}\right)$ as shown in Fig. 2 indicates similar peaks to those observed for the as-deposited $\mathrm{Ca}-\mathrm{P}$ coating. In addition to this low levels of fluorine were detected for this in situ annealed 


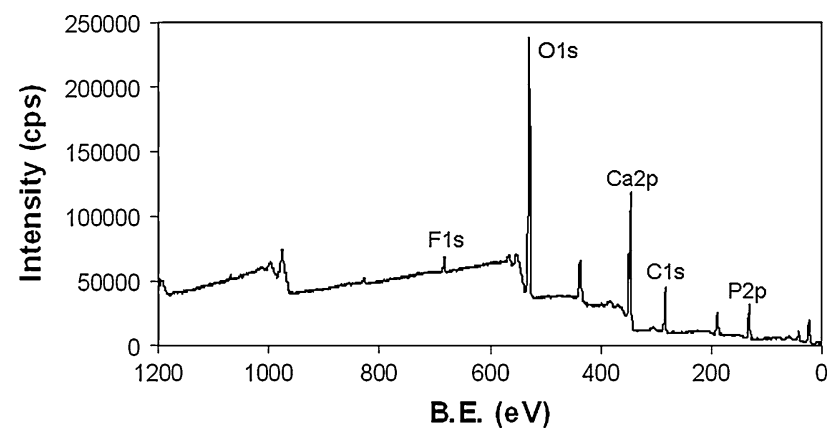

Fig. 2 XPS wide energy survey scan for the ISA $500^{\circ} \mathrm{C}$ sample (ISA-in situ annealed)

$500^{\circ} \mathrm{C} \mathrm{Ca}-\mathrm{P}$ coating as shown in Table 1 and Fig. 2. It is thought that the source of the fluorine signal observed in the in situ annealed Ca-P coatings may be due to PTFE materials used in the sputtering sources, however, as yet this has not been confirmed. The results for the fitted high resolution XPS data obtained for the $\mathrm{C} 1 \mathrm{~s}, \mathrm{O} 1 \mathrm{~s}, \mathrm{Ca} 2 \mathrm{p}$ and $\mathrm{P} 2 \mathrm{p}$ regions of the $\mathrm{Ca}-\mathrm{P}$ in situ annealed to $500^{\circ} \mathrm{C}\left(0^{\circ}\right.$ TOA) are presented in Fig. 3 along with the tabulated data for the same results in Tables 1, 2, 3, 4, 5, 6 (which also includes the data for coatings analysed at TOAs of $45^{\circ}$ and $75^{\circ}$ for comparison). The $\mathrm{C} 1 \mathrm{~s}$ region, has been curve fitted with three different components. The dominant peak $(285.0 \mathrm{eV})$ is attributed to hydrocarbon species, i.e. $\mathrm{C}-\mathrm{C}$ and/or $\mathrm{C}-\mathrm{H}$, present as a result of adventitious carbon contamination [44]. The other peaks at 286.5 and $289.7 \mathrm{eV}$ are typical of $\mathrm{C}-\mathrm{O}$ bonding and $\mathrm{C}=\mathrm{O}$ bonding, respectively $[7,47]$. The corresponding O1s peak can be fitted into two separate peaks. The most intense component at $531.2 \mathrm{eV}$ corresponds to an O-P bonded species and the second peak at $532.5 \mathrm{eV}$ can be attributed to oxygen bonded to carbon and/or an $\mathrm{OH}^{-}$species $[7,48]$. The Ca2p region for this in situ annealed coating at $500^{\circ} \mathrm{C}$, exhibits a well-resolved doublet with a $\mathrm{Ca} 2 \mathrm{p}_{3 / 2}$ component at $347.5 \mathrm{eV}$ and a $\mathrm{Ca} 2 \mathrm{p}_{1 / 2}$ component at $351.0 \mathrm{eV}[7,48]$. The $\mathrm{Ca} 2 \mathrm{p}_{1 / 2}$ and $\mathrm{Ca} 2 \mathrm{p}_{3 / 2}$ bands are separated by approximately $3.5 \mathrm{eV}$ and have the correct relative intensity ratio of $3: 1$. The fitted
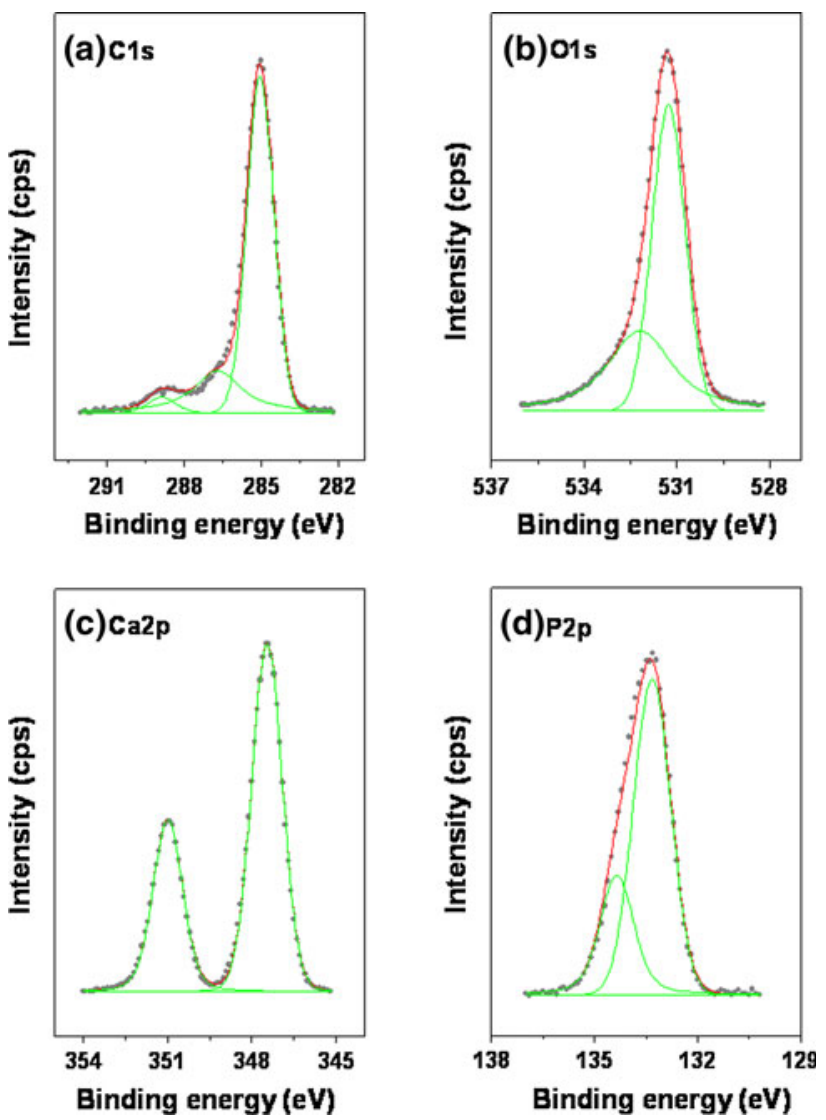

Fig. 3 High resolution XPS spectra of a C1s, b O1s, c Ca2p and d P2p for the ISA $500^{\circ} \mathrm{C}$ sample (ISA-in situ annealed)

P2p envelope indicates the presence of two components with B.E. positions of 133.3 and $134.2 \mathrm{eV}$, which correspond to the $\mathrm{P} 2 \mathrm{p}_{3 / 2}$ and $\mathrm{P} 2 \mathrm{p}_{1 / 2}$ states of phosphorus in a Ca-P material, respectively [7, 49]. No peaks indicative of titanium or any oxides of titanium were detected for this particular surface. The $\mathrm{Ca} / \mathrm{P}$ ratio of the $\mathrm{Ca}-\mathrm{P}$ coating in situ annealed to $500^{\circ} \mathrm{C}\left(0^{\circ} \mathrm{TOA}\right)$ was 1.49 , as reported in Table 4, a value slightly lower than expected for stoichiometric HA (1.67) [5]. Similar peak positions are also observed for the $\mathrm{Ca}-\mathrm{P}$ coating in situ annealed to $500^{\circ} \mathrm{C}$ at
Table 1 XPS peak position data for the $\mathrm{Ca}-\mathrm{P} / \mathrm{TiO}_{2}$ coatings at $0^{\circ} \mathrm{C}$ TOA (ISA-in situ annealed)

\begin{tabular}{|c|c|c|c|c|c|c|c|c|}
\hline \multirow[t]{2}{*}{ Sample } & \multicolumn{8}{|c|}{ Peak position (binding energy) eV } \\
\hline & $\mathrm{C} 1 \mathrm{~s}$ & O1s & $\mathrm{Ca} 2 \mathrm{p}_{3 / 2}$ & $\mathrm{Ca} 2 \mathrm{p}_{1 / 2}$ & Ti2 $\mathrm{p}_{3 / 2}$ & $\operatorname{Ti} 2 \mathrm{p}_{1 / 2}$ & $\mathrm{P} 2 \mathrm{p}$ & F1s \\
\hline ISA 500 & $\begin{array}{l}285 \\
286.5 \\
289.7\end{array}$ & $\begin{array}{l}531.2 \\
532.5\end{array}$ & 347.5 & 351 & - & - & $\begin{array}{l}133.3 \\
134.2\end{array}$ & 685.3 \\
\hline ISA 600 & $\begin{array}{l}285 \\
286.4 \\
289.4\end{array}$ & $\begin{array}{l}531.2 \\
532.2\end{array}$ & 347.6 & 351.1 & 458.8 & 463.5 & $\begin{array}{l}133.3 \\
134.3\end{array}$ & 684.5 \\
\hline ISA 700 & $\begin{array}{l}285 \\
286.4 \\
288.9\end{array}$ & $\begin{array}{l}531.2 \\
532.1\end{array}$ & 347.5 & 351 & 458.6 & 463.8 & $\begin{array}{l}133.2 \\
134.1\end{array}$ & 685 \\
\hline
\end{tabular}


Table 2 XPS peak position data for the $\mathrm{Ca}-\mathrm{P} / \mathrm{TiO}_{2}$ coatings at $45^{\circ} \mathrm{C}$ TOA (ISA-in situ annealed)
Table 3 XPS peak position data for the $\mathrm{Ca}-\mathrm{P} / \mathrm{TiO}_{2}$ coatings at $75^{\circ} \mathrm{C}$ TOA (ISA-in situ annealed)

\begin{tabular}{lllllllll}
\hline Sample & \multicolumn{7}{l}{ Peak position (binding energy) $\mathrm{eV}$} \\
\cline { 2 - 8 } & $\mathrm{C} 1 \mathrm{~s}$ & $\mathrm{O} 1 \mathrm{~s}$ & $\mathrm{Ca} 2 \mathrm{p}_{3 / 2}$ & $\mathrm{Ca} 2 \mathrm{p}_{1 / 2}$ & $\mathrm{Ti2} \mathrm{p}_{3 / 2}$ & Ti2 $\mathrm{p}_{1 / 2}$ & $\mathrm{P} 2 \mathrm{p}$ & $\mathrm{F} 1 \mathrm{~s}$ \\
\hline ISA 500 & 285 & 531.2 & 347.4 & 350.9 & - & - & 133.2 & 685.3 \\
& 286.4 & 532.2 & & & & & 134.1 & \\
& 288.6 & & & & & & & \\
ISA 600 & 285 & 531.2 & 347.4 & 351 & 458.8 & 463.8 & 133.2 & 684.5 \\
& 286.4 & 532.5 & & & & & 134.1 & \\
& 289.4 & & & & & & & \\
ISA 700 & 285 & 531.3 & 347.5 & 351 & 458.7 & 463.8 & 133.1 & 685.2 \\
& 286.4 & 532.5 & & & & & 134.1 & \\
& 289 & & & & & & & \\
\hline
\end{tabular}

\begin{tabular}{|c|c|c|c|c|c|c|c|c|}
\hline \multirow[t]{2}{*}{ Sample } & \multicolumn{8}{|c|}{ Peak position (binding energy) eV } \\
\hline & $\mathrm{C} 1 \mathrm{~s}$ & $\mathrm{O} 1 \mathrm{~s}$ & $\mathrm{Ca} 2 \mathrm{p}_{3 / 2}$ & $\mathrm{Ca} 2 \mathrm{p}_{1 / 2}$ & $\mathrm{Ti} 2 \mathrm{p}_{3 / 2}$ & $\mathrm{Ti} 2 \mathrm{p}_{1 / 2}$ & $\mathrm{P} 2 \mathrm{p}$ & F1s \\
\hline ISA 500 & $\begin{array}{l}285 \\
286.5 \\
288.5\end{array}$ & $\begin{array}{l}531.3 \\
532.2\end{array}$ & 347.4 & 350.9 & - & - & $\begin{array}{l}133.1 \\
134.1\end{array}$ & 684.4 \\
\hline ISA 600 & $\begin{array}{l}285 \\
286.5 \\
288.9\end{array}$ & $\begin{array}{l}531.2 \\
532.3\end{array}$ & 347.4 & 350.9 & - & - & $\begin{array}{l}133.2 \\
134.3\end{array}$ & 684.4 \\
\hline ISA 700 & $\begin{array}{l}285 \\
286.4 \\
289.2\end{array}$ & $\begin{array}{l}531.2 \\
532.2\end{array}$ & 347.6 & 351.1 & 458.7 & 464.1 & $\begin{array}{l}133.1 \\
134.1\end{array}$ & 685.1 \\
\hline
\end{tabular}

Table 4 XPS quantitative data for the $\mathrm{Ca}-\mathrm{P} / \mathrm{TiO}_{2}$ coatings at $0^{\circ} \mathrm{C}$ TOA (ISA-in situ annealed)

\begin{tabular}{|c|c|c|c|c|c|c|c|}
\hline \multirow[t]{2}{*}{ Sample } & \multicolumn{6}{|c|}{$\%$ Atomic concentration } & \multirow[b]{2}{*}{$\mathrm{Ca} / \mathrm{P}$} \\
\hline & $\mathrm{C} 1 \mathrm{~s}$ & $\mathrm{O} 1 \mathrm{~s}$ & $\mathrm{Ca} 2 \mathrm{p}$ & $\mathrm{P} 2 \mathrm{p}$ & Ti2p & F1s & \\
\hline ISA 500 & 28.6 & 44.5 & 14.5 & 9.7 & - & 2.8 & 1.49 \\
\hline ISA 600 & 29.4 & 41.5 & 13.4 & 8.5 & 0.4 & 6.8 & 1.57 \\
\hline ISA 700 & 30.1 & 41.1 & 13.6 & 6.8 & 0.7 & 7.7 & 2.00 \\
\hline
\end{tabular}

Table 5 XPS quantitative data for the $\mathrm{Ca}-\mathrm{P} / \mathrm{TiO}_{2}$ coatings at $45^{\circ} \mathrm{C}$ TOA (ISA-in situ annealed)

\begin{tabular}{|c|c|c|c|c|c|c|c|}
\hline \multirow[t]{2}{*}{ Sample } & \multicolumn{6}{|c|}{$\%$ Atomic concentration } & \multirow[b]{2}{*}{$\mathrm{Ca} / \mathrm{P}$} \\
\hline & $\mathrm{C} 1 \mathrm{~s}$ & O1s & $\mathrm{Ca} 2 \mathrm{p}$ & $\mathrm{P} 2 \mathrm{p}$ & Ti2p & $\mathrm{F} 1 \mathrm{~s}$ & \\
\hline ISA 500 & 35.6 & 38.8 & 13.7 & 9.6 & - & 2.1 & 1.43 \\
\hline ISA 600 & 34.3 & 39.2 & 13.3 & 8.7 & 0.5 & 4.1 & 1.53 \\
\hline ISA 700 & 33.0 & 38.6 & 14.3 & 7.1 & 0.7 & 6.4 & 2.01 \\
\hline
\end{tabular}

$45^{\circ}$ and $75^{\circ}$ take off angles, as shown in Tables 2 and 3, respectively. No significant difference was observed in the $\mathrm{Ca} / \mathrm{P}$ ratio for the spectra collected at either of these take off angles, as shown in Tables 5 and 6.

However, after in situ annealing of the $\mathrm{Ca}-\mathrm{P}$ coatings deposited onto the titanium layer to $600^{\circ} \mathrm{C}\left(0^{\circ} \mathrm{TOA}\right)$,
Table 6 XPS quantitative data for the $\mathrm{Ca}-\mathrm{P} / \mathrm{TiO}_{2}$ coatings at $75^{\circ} \mathrm{C}$ TOA (ISA-in situ annealed)

\begin{tabular}{|c|c|c|c|c|c|c|c|}
\hline \multirow[t]{2}{*}{ Sample } & \multicolumn{6}{|c|}{$\%$ Atomic concentration } & \multirow[b]{2}{*}{$\mathrm{Ca} / \mathrm{P}$} \\
\hline & $\mathrm{C} 1 \mathrm{~s}$ & O1s & $\mathrm{Ca} 2 \mathrm{p}$ & $\mathrm{P} 2 \mathrm{p}$ & Ti2p & F1s & \\
\hline ISA 500 & 46.9 & 31.5 & 11.8 & 7.8 & - & 1.9 & 1.51 \\
\hline ISA 600 & 33.2 & 40.2 & 11.1 & 6.1 & - & 9.7 & 1.83 \\
\hline ISA 700 & 36.5 & 35.9 & 14.6 & 6.4 & 0.6 & 6.0 & 2.26 \\
\hline
\end{tabular}

significant differences were observed and a weak Ti2p peak was detected. The distribution of peaks in the Ti2p envelope for this coating indicates the presence of $\mathrm{TiO}_{2}$ with peaks at $458.8 \mathrm{eV}\left(\mathrm{Ti} 2 \mathrm{p}_{3 / 2}\right)$ and at $463.5 \mathrm{eV}\left(\mathrm{Ti} 2 \mathrm{p}_{1 / 2}\right)$ [50-52] as given in Table 1. No significant change was observed in the $\mathrm{Ca} / \mathrm{P}$ ratio of this coating (1.57) when compared to that observed for the coating in situ annealed to $500^{\circ} \mathrm{C}\left(0^{\circ} \mathrm{TOA}\right)$ at 1.49 . Furthermore, no significant differences in the BE contributions of the fitted XPS spectral data for the $\mathrm{Ca}-\mathrm{P}$ coatings in situ annealed to $600^{\circ} \mathrm{C}\left(0^{\circ} \mathrm{TOA}\right)$ were evident. Similar results were observed for the fitted spectra for the in situ annealed coating at $600^{\circ} \mathrm{C}\left(45^{\circ} \mathrm{TOA}\right)$, with a $\mathrm{Ca} / \mathrm{P}$ ratio of 1.53 . However, the XPS data for the in situ annealed $600^{\circ} \mathrm{C}$ at a TOA of $75^{\circ}$ indicates a significant increase in the $\mathrm{Ca} / \mathrm{P}$ 
ratio to 1.83 . In addition, no peaks indicative of titanium (or oxides of titanium) were observed for these coatings in situ annealed to $600^{\circ} \mathrm{C}$ at a TOA of $75^{\circ}$.

In comparison, in situ annealing of the $\mathrm{Ca}-\mathrm{P}$ coatings to $700^{\circ} \mathrm{C}\left(0^{\circ} \mathrm{TOA}\right)$ produced surfaces that had a very high $\mathrm{Ca} / \mathrm{P}$ ratio (2.00) as given by the XPS data in Table 4 . The fitted Ti2p envelope indicated the presence of peaks indicative of $\mathrm{TiO}_{2}$ at $458.6 \mathrm{eV}\left(\mathrm{Ti}_{2} \mathrm{p}_{3 / 2}\right)$ and at $463.8 \mathrm{eV}$ $\left(\mathrm{Ti} 2 \mathrm{p}_{1 / 2}\right.$ ) [50-52]. Similarly, the $\mathrm{Ca} / \mathrm{P}$ ratio of the coating in situ annealed to $700^{\circ} \mathrm{C}\left(45^{\circ} \mathrm{TOA}\right)$ was high at 2.01 as given in Table 5. The fitted XPS spectral data did not show any significant differences when compared to those observed after in situ annealing to $700^{\circ} \mathrm{C}\left(0^{\circ} \mathrm{TOA}\right)$, as shown in Table 2 . The $\mathrm{Ca} / \mathrm{P}$ ratio did however increase significantly after analysing the $700^{\circ} \mathrm{C}$ in situ annealed coating at a TOA of $75^{\circ}$ to 2.26 , as shown in Table 6. This result is not un-expected for coatings produced using this method and indicates a calcium rich surface. In addition to this, peaks indicative of $\mathrm{TiO}_{2}$ are clearly observed in the Ti2p spectral envelope for the $700^{\circ} \mathrm{C}$ in situ annealed coating $\left(75^{\circ} \mathrm{TOA}\right)$.

The stoichiometry obtained from the XPS analysis of the coatings annealed to 500 and $600^{\circ} \mathrm{C}$ at TOAs of $0^{\circ}$ and $45^{\circ}$ are close to that of tri-calcium phosphate (TCP) $(\mathrm{Ca} / \mathrm{P}-$ 1.5). Despite this the XRD data clearly shows the presence of HA material only. This may suggest that the levels of TCP are below the detection limits of the XRD technique or that the coatings in situ annealed at these temperatures have a phosphorus rich surface [23]. This is also the case for the $500^{\circ} \mathrm{C}$ surface analysed at a TOA of $75^{\circ}$. In contrast to these results, the $\mathrm{Ca} / \mathrm{P}$ ratios obtained for the surfaces in situ annealed to $700^{\circ} \mathrm{C}$ (at all TOAs utilised in this study) indicated $\mathrm{Ca} / \mathrm{P}$ ratios of $2.0-2.26$ which highlights the calcium rich nature of the uppermost surfaces created here. This is also true for the $600^{\circ} \mathrm{C}$ in situ annealed sample at a TOA of $75^{\circ}$. These XPS results clearly show an increase in the $\mathrm{Ca} / \mathrm{P}$ ratio with increasing in situ annealing temperature, as has been observed in previous studies [23]. In addition to this, the data presented here also confirm that this process is predominantly a surface phenomenon given the significant increases in the $\mathrm{Ca} / \mathrm{P}$ ratio observed at the $75^{\circ}$ TOAs for the 600 and $700^{\circ} \mathrm{C}$ samples. This supports previous assumptions that the increase in the $\mathrm{Ca} / \mathrm{P}$ ratio as a result of increasing annealing temperature (in situ) is a consequence of the evaporation of volatile phosphorus species from the surfaces of such sputter deposited samples [23]. Previous work, which utilised post-deposition annealed of similar calcium phosphate samples in air showed an increase in the $\mathrm{Ca} / \mathrm{P}$ ratio with increasing annealing temperature (to a maximum of $500^{\circ} \mathrm{C}$ ), which is consistent with the results observed here [7, 10, 13]. However, in previous studies performed using post deposition annealing in air to 600 and $700^{\circ} \mathrm{C}$, the $\mathrm{Ca} / \mathrm{P}$ ratio is seen to fall significantly and in these cases, the incorporation of $\mathrm{TiO}_{2}$ has been attributed to the stability of the coatings and the impediment of the evaporation of any phosphorus species. In the case of the in situ annealed samples, thermal processing was carried out over a period of $5 \mathrm{~h}$ (when compared to the $2 \mathrm{~h}$ for the post deposition annealed samples in previous studies) [23]. As such, the increase in the $\mathrm{Ca} / \mathrm{P}$ ratio observed for the in situ annealing samples (especially in the outermost surfaces regions, as given by the change in the TOA of the XPS analysis) could be explained by this increased annealing time, which has resulted in the evaporation of any volatile phosphorus products from the surface leaving a more $\mathrm{Ca}$ rich layer. From these XPS results it is apparent that only the $700^{\circ} \mathrm{C}$ in situ annealed sample shows a hybrid $\mathrm{HA} / \mathrm{TiO}_{2}$ outermost surface layer when compared to the 500 and $600^{\circ} \mathrm{C}$ in situ annealed coatings, and concurs with the data obtained from the XRD analyses. The presence of $\mathrm{CaTiO}_{3}$ in the outmost surface of the $700^{\circ} \mathrm{C}$ in situ annealed samples can be ruled out due to the fact that peak positions observed for the Ti2p envelope given in Tables 1, 2, 3 (for TOAs of $0^{\circ}, 45^{\circ}$ and $75^{\circ}$, respectively) correspond to that for $\mathrm{TiO}_{2}$ at approximately $458.8 \mathrm{eV}$ [53]. Typically, the titanium bonding states for $\mathrm{CaTiO}_{3}$ are observed around $459.2 \mathrm{eV}$ [53].

\subsection{AFM}

The AFM images of the Ti-6Al-4V substrate in Fig. $4 \mathrm{a}$ $(5 \mu \mathrm{m} \times 5 \mu \mathrm{m})$ show a series of surface features including random abrasion scratches, small hillocks, pits and fissures. In the case of the abrasion scratches these range in width from 0.3 to $1.0 \mu \mathrm{m}$ and in depth from 0.1 to $0.3 \mu \mathrm{m}$. For the Ti-6Al-4V substrate coated with a titanium layer, titanium crystallites of up to $200 \mathrm{~nm}$ in diameter seem to have formed preferentially around the more prominent surface features on the substrate as shown in Fig. $4 \mathrm{~b}(5 \mu \mathrm{m} \times 5 \mu \mathrm{m})$. The corresponding AFM images for the as-deposited Ca-P coating as illustrated in Fig. $4 \mathrm{c}(5 \mu \mathrm{m} \times 5 \mu \mathrm{m})$ show a relative tendency for the coatings to mimic the substrate topography and to conform to striations and defects produced by the abrasion of the substrate. However, there is evidence from the AFM to suggest that there has been significant in-filling of the larger pits and fissures on the substrate surface, which is typical of previous studies utilising similar RF magnetron sputter deposited calcium phosphate coatings [7, 10, 23].

The AFM image for the $500^{\circ} \mathrm{C}$ in situ annealed surface, as shown in Fig. $5 \mathrm{a}(10 \mu \mathrm{m} \times 10 \mu \mathrm{m})$, appears to indicate that the coatings transforms into one that exhibits a series of sharp columnar features right across the coating surface and range in size from 0.1 to $0.5 \mu \mathrm{m}$. These values approximate closely to those observed before for sputter deposited $\mathrm{Ca}-\mathrm{P}$ coatings $[7,10,23]$. The coating in situ 

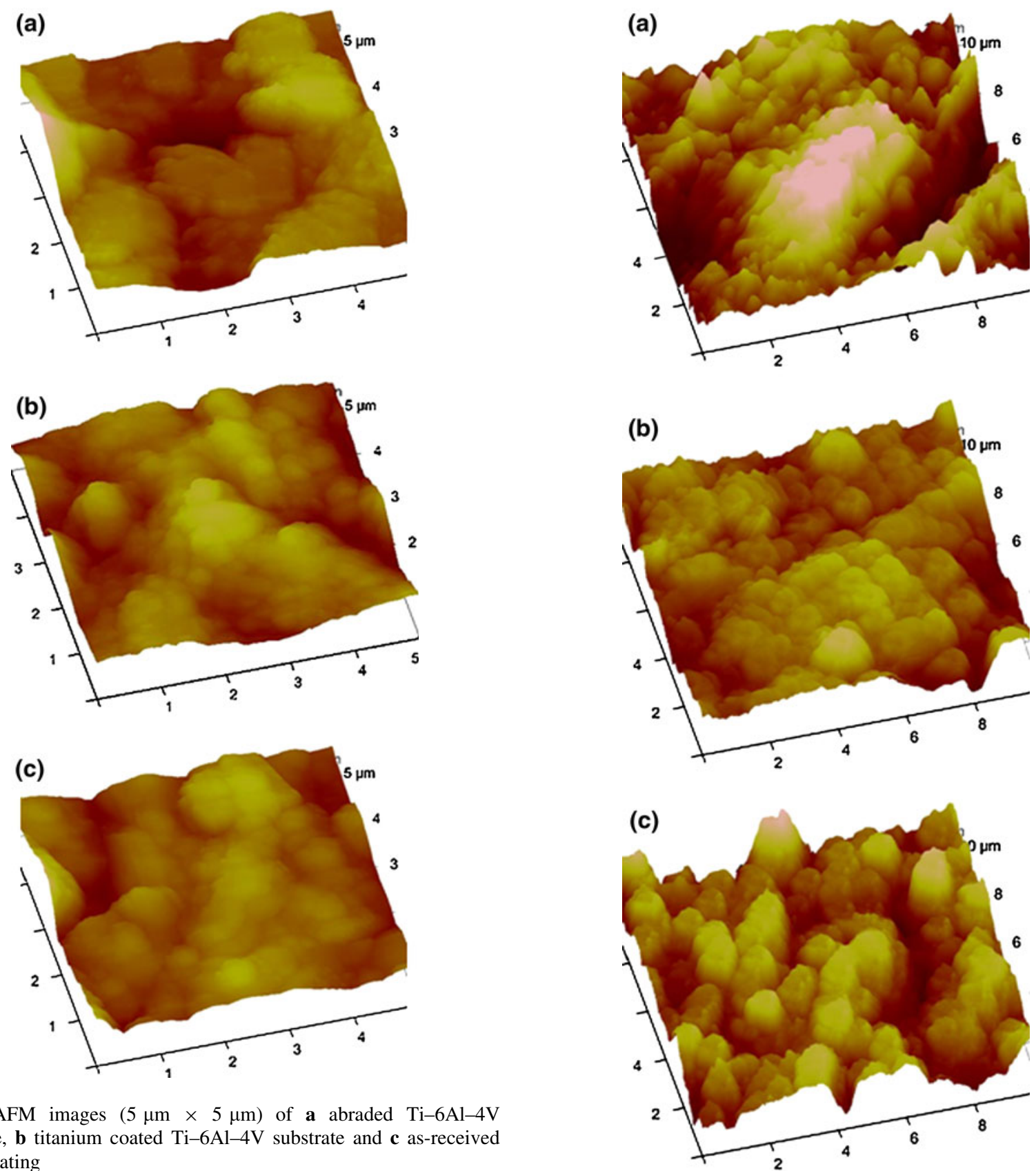

Fig. 4 AFM images $(5 \mu \mathrm{m} \times 5 \mu \mathrm{m})$ of a abraded Ti-6Al-4V substrate, $\mathbf{b}$ titanium coated $\mathrm{Ti}-6 \mathrm{Al}-4 \mathrm{~V}$ substrate and $\mathbf{c}$ as-received Ca-P coating

annealed to $600^{\circ} \mathrm{C}$ has transformed into one that exhibits large spherical features that are between 0.5 and $1.5 \mu \mathrm{m}$, as shown in Fig. 5b. The sample in situ annealed to $700^{\circ} \mathrm{C}$ shows further significant change in the surface morphology, with the larger columnar structures becoming more prominent. Small nanocrystallite features of up to $100 \mathrm{~nm}$ are also observed across the entire surface of the $700^{\circ} \mathrm{C}$ in situ annealed samples and are organised into small chains as shown in Fig. 5c. Similar data were obtained for such coatings in previous studies [23]. These AFM results, as with the XPS and XRD data, clearly indicate that only the $700^{\circ} \mathrm{C}$ in situ annealed coatings shows a hybrid $\mathrm{HA} / \mathrm{TiO}_{2}$

Fig. 5 AFM images $(10 \mu \mathrm{m} \times 10 \mu \mathrm{m})$ of a ISA $500^{\circ} \mathrm{C}$, b ISA $600^{\circ} \mathrm{C}$ and $\mathbf{c}$ ISA $700^{\circ} \mathrm{C}$ samples (ISA-in situ annealed)

outermost surface layer when compared to the $500^{\circ} \mathrm{C}$ and $600^{\circ} \mathrm{C}$ in situ annealed surfaces.

\subsection{Protein adsorption}

\subsubsection{Surface-MALDI}

Surface-MALDI has proven to be a very useful technique at detecting proteins adsorbed to surfaces [42, 43], 
particularly from complex protein solutions, such as serum. Indeed, MALDI appears to be a suitable technique that has the promise to detect multiply adsorbed proteins on planar surfaces exposed to serum. In particular, it has the sensitivity to detect proteins with concentrations in the low $\mathrm{ng} / \mathrm{cm}^{2}$ range, over areas of a few $\mathrm{mm}^{2}$. The experiments were chosen to mimic the cell culture environment in which the cells are suspended in 10\% FBS solution. The question asked was, are there serum proteins that adsorb to the different coatings that could influence the cell behaviour? Our methodology is initially based on determining whether surface-MALDI can detect proteins adsorbed to the different coatings produced here to be used for bone regeneration, and potentially identifying the species present based on existing knowledge of the composition of serum. The knowledge generated will be utilised in future work where a more comprehensive programme of cellular responses to the individual components detected from the serum experiments will be undertaken.

Figure 6 shows a surface-MALDI spectrum recorded from the $\mathrm{Ti}-6 \mathrm{Al}-4 \mathrm{~V}$ substrate after $1 \mathrm{~h}$ exposure to $10 \%$ FBS. Figure 6a shows the spectrum ranging from 5 to $100 \mathrm{kDa}$, and Fig. $6 \mathrm{~b}$ shows the expanded plot from 5 to $25 \mathrm{kDa}$. Clearly, a large number of peaks are present in the
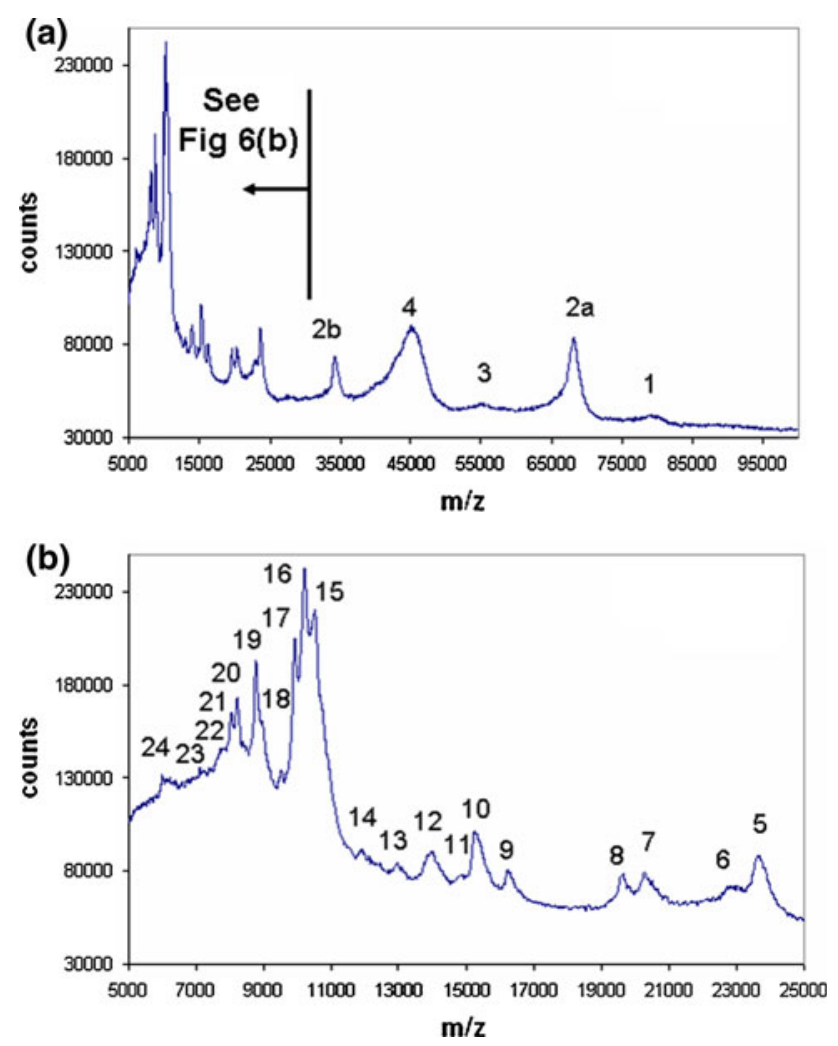

Fig. 6 Surface-MALDI data recorded from the Ti-6Al-4V substrate after $1 \mathrm{~h}$ exposure to $10 \%$ FBS where a 5-100 kDa spectrum range, and $\mathbf{b} 5-25 \mathrm{kDa}$ spectrum range spectra indicating that many different serum proteins adsorb to the Ti-6Al-4V surface. The major peaks in the spectrum, along with potential assignments are summarised in Table 7. A combination of literature $[38,54]$ reports and known bovine and human proteins in the iProClass database [55] were used to interpret the spectra. We tentatively base the assignments on knowledge of proteins detected in human serum with medium to high concentrations, since such knowledge is unavailable for bovine serum. Serum albumin is clearly the major protein detected with two peaks at 68.3 and $34.3 \mathrm{kDa}$ corresponding to the $[\mathrm{M}+\mathrm{H}]^{+},[2 \mathrm{M}+\mathrm{H}]^{+}$ions, respectively. The highest molecular weight protein detected is assigned to adsorbed transferrin, with a molecular weight of $79.4 \mathrm{kDa}$. There are a number of high molecular weight proteins known to be in serum at quite concentrations that are either not detected or not considered due to the limitations in detection based on instrument limitations including fibronectin (MW 250 $\mathrm{kDa}$ ), alpha-2-macroglobulin (MW $160 \mathrm{kDa}$ ), ceruplasmin (MW $120 \mathrm{kDa}$ ), plasminogen (MW $88 \mathrm{kDa}$ ), integrin b-1 (MW $88 \mathrm{kDa}$ ), and cone cGP-specific $3^{\prime}, 5^{\prime}$-cyclic phosphodiesterase $\alpha$-subunit. It cannot be ruled out that some of the low molecular weight species detected are fragments of these proteins. In addition, we are also assuming that FBS has very few immunoglobulins present and that the preparation and heat inactivation of FBS eliminates plasma proteins involved in coagulation and the complement proteins. However, it should be noted that antithrombin III has been detected in FBS using LC-MS [4].

The largest and most broad peak occurs in the molecular weight range $38.4-51.7 \mathrm{kDa}$. Unfortunately due to the low mass resolution of the MALDI instrument operating in linear mode the peak is unresolvable. The broadness of the peak most likely corresponds to spectral overlap from adsorption of a large number of the most abundant serum proteins in this molecular weight range including haptoglobulin $(44,859 \mathrm{Da}), \alpha$-1-antitrypsin (46,104 Da), $\alpha$-1-antichymotrypsin $(46,954 \mathrm{Da})$, beta-2-glycoprotein (38,252 Da), alpha-2-hs-glycoprotein (39,325 Da), and $\alpha-1$ 1 -microglobulin and inter- $\alpha$-trypsin inhibitor light chain $(39,232 \mathrm{Da})$. Similarly a small but broad peak is detected in the mass range 52.7-57.1 kDa. A number of known proteins possibly adsorb in this mass range that are known to be quite concentrated in human serum including vitamin-d-binding protein $(53,342 \mathrm{Da})$, vitronectin $(53,575 \mathrm{Da})$, alpha-1Bglycoprotein $(54,273 \mathrm{Da})$, hemopexin $(51,676 \mathrm{Da})$, antithrombin III (52,347 Da), and $\alpha-2$ antiplasmin $(54,711 \mathrm{Da})$. Furthermore, it should be noted that the low intensity of the peak suggests that the surface concentration of these components is quite low.

The large peak at $\sim 23.7 \mathrm{kDa}$ does not have any obvious candidates from the literature. However, it has been shown that growth factors can be present in FBS [4], 
Table 7 Summary of the surface-MALDI data generated from the Ti-6Al-4V substrate exposed to $10 \%$ FBS and possible assignments based on information obtained from the iProClass database for bovine proteins (http://pir.georgetown.edu/)

\begin{tabular}{|c|c|c|c|c|c|}
\hline Peak no. & $\begin{array}{l}\text { Detected } \\
\text { MW (kDa) }\end{array}$ & Possible assignment & $\begin{array}{l}\text { Known } \\
\text { MW (Da) }\end{array}$ & $\begin{array}{l}\text { Concentration }{ }^{\mathrm{a}} \\
\text { in serum }(\mu \mathrm{g} / \mathrm{ml})\end{array}$ & ID \\
\hline 1 & 79.4 & Transferrin & 77753 & 2660 & A60166 \\
\hline $2 a, 2 b$ & $68.3,34.3$ & Albumin & 69293 & 45000 & ABBOS \\
\hline 3 & $52.7-57.1$ & Vitamin-d-binding protein & 53342 & 400 & VTDB \\
\hline 3 & $52.7-57.1$ & Vitronectin & 53575 & 340 & Q3ZBS7 \\
\hline 3 & $52.7-57.1$ & $\alpha$-1B-Glycoprotein & $54273(\mathrm{H})$ & 225 & P04217 \\
\hline 3 & $52.7-57.1$ & Hemopexin & 51676 & 200 & Q3SZV7 \\
\hline 3 & $52.7-57.1$ & Antithrombin III & 52347 & $145^{\mathrm{b}}$ & ANT3 \\
\hline 3 & $52.7-57.1$ & $\alpha-2$ Antiplasmin & 54711 & $60^{\mathrm{b}}$ & $\mathrm{A} 2 \mathrm{AP}$ \\
\hline 4 & $38.4-51.0$ & Haptoglobulin & 44859 & 1365 & Q2TBU0 \\
\hline 4 & $38.4-51.0$ & $\alpha$-1-Antitrypsin & 46104 & 1235 & A1AT \\
\hline 4 & $38.4-51.0$ & $\alpha-1$-Antichymotrypsin & 46954 & 450 & S66289 \\
\hline 4 & $38.4-51.0$ & $\beta$-2-Glycoprotein & 38252 & 220 & $\mathrm{APOH}$ \\
\hline 4 & $38.4-51.0$ & $\alpha$-2-hs-Glycoprotein & $39325(\mathrm{H})$ & 625 & A2HS \\
\hline 4 & $38.4-51.0$ & $\begin{array}{l}\alpha-1-1-\text { Microglobulin and inter- } \alpha \text {-trypsin } \\
\text { inhibitor light chain }\end{array}$ & 39232 & Unknown & AMBP \\
\hline 5 & 23.7 & Platelet-derived growth factor beta isoform 1 & 23723 & Unknown & Q58D48 \\
\hline 5 & 23.7 & Interleukin 6 (IL-6) & 23759 & Unknown & P26892 \\
\hline 6 & 23.0 & $\alpha$-1-Acid-glycoprotein & 23182 & 870 & A1AG \\
\hline 7 & 20.3 & Plasma retinol binding protein & 21069 & 55 & P18902 \\
\hline 7 & 20.3 & Interleukin 10 (IL-10) & 20411 & Unknown & P43480 \\
\hline 7 & 20.3 & Fibroblast growth factor 12 isoform 2 & 20424 & Unknown & Q5E9M0 \\
\hline 7 & 20.3 & Fibronectin variable factor & 20378 & Unknown & Q9MZ31 \\
\hline 7 & 20.3 & Transforming growth factor beta regulator 1 & 20429 & Unknown & Q0V8K6 \\
\hline 8 & 19.7 & Insulin-like growth factor II (IGF-II) & 19682 & Unknown & P07456 \\
\hline 9 & 16.3 & LPS-binding protein & 16980 & 18 & Q2KVH3 \\
\hline 10 & 15.3 & Apolipoprotein B100 & $15653(\mathrm{H})$ & 1330 & Q13789 \\
\hline 10 & 15.3 & Prealbumin & 15727 & 345 & O46375 \\
\hline 10 & 15.3 & Hemoglobin beta fetal chain & 15859 & Unknown & HBBF \\
\hline 11 & 15.0 & Hemoglobin $\alpha$-chain & 15184 & Unknown & HBA \\
\hline 12 & 14.1 & Serum amyloid A & 14516 & 10 & P35541 \\
\hline 13 & 13.1 & $\beta$-2-Microglobulin & 13667 & 16 & P01888 \\
\hline 14 & 11.9 & Unknown & & & \\
\hline 15 & 10.5 & Apolipoprotein A-II & 11202 & 460 & APA2 \\
\hline 16 & 10.2 & Apolipoprotein C-III & 10692 & 124 & P19035 \\
\hline 17 & 9.9 & Alpha 1-antichymotrypsin (Fragment) & 9794 & Unknown & Q28922 \\
\hline 18 & 9.5 & Platelet factor 4 & 9523 & Unknown & P02777 \\
\hline 18 & 9.5 & Apolipoprotein C-1 & $9332(\mathrm{H})$ & 7 & P02654 \\
\hline 19 & 8.7 & Apolipoprotein C-II & 8606 & 33 & P19034 \\
\hline 20 & 8.2 & Unknown & & & \\
\hline 21 & 8.0 & Unknown & & & \\
\hline 22 & 7.7 & Unknown & & & \\
\hline 23 & 7.1 & Unknown & & & \\
\hline 24 & 6.0 & Unknown & & & \\
\hline
\end{tabular}

${ }^{a}$ Concentration in human serum [3], unknown for FBS. (H) Human assignment. ${ }^{\mathrm{b}}$ Detected in FBS in high abundance [4] 
however, there were major differences from supplier to supplier making it difficult to assign any peaks to these protein species. One possible candidate is platelet-derived growth factor beta isoform 1 (23,723 Da) that been cited in the iProClass database. An additional candidate could be Interleukin 6 (IL-6) $(23,759 \mathrm{Da})$, which has been detected adsorbed to heparin coated extracorporeal circuits exposed to plasma [56]. Furthermore, there are additional peaks in the spectrum that are potentially growth factors at mass values 20.3 and $19.7 \mathrm{kDa}$ for fibroblast growth factor 12 isoform $2(20,424 \mathrm{Da})$ or transforming growth factor beta regulator $1(20,429 \mathrm{Da})$ and insulin-like growth factor II (IGF-II) (19,682 Da). Their concentration in FBS is unknown. Other candidates for the peak at $20.3 \mathrm{kDa}$ include Interleukin 10 (IL-10) $(20,411 \mathrm{Da})$ and fibronectin variable factor $(20,378 \mathrm{Da})$.

There are a number of proteins detected that are tentatively assigned to apolipoproteins. These include apolipoprotein B100 (15.3 kDa), apolipoprotein A-II (10.5 kDa), apolipoprotein C-III $(10.2 \mathrm{kDa})$, apolipoprotein C-1 $(9.5 \mathrm{kDa})$, and apolipoprotein C-II $(8.7 \mathrm{kDa})$. However, the peak at $15.3 \mathrm{kDa}$ has several other possible overlapping candidates including prealbumin $(15,727 \mathrm{Da})$, and hemoglobin beta fetal chain $(15,859 \mathrm{Da})$. Interestingly, no apolipoprotein A1 (Apo-A1, MW 30,276 Da) or apolipoprotein E (Apo E, MW 35,980 Da) is detected. Both these proteins are quite abundant in serum and have been associated with opsonization of particle drug carriers and wear particles in orthopaedics. Apo $\mathrm{E}$ has been implicated in adsorbing to the surface of phosphatidyl serine containing liposomes [57], and Apo A1 has been shown to be a key protein adsorbing from serum onto wear particles in hip-joint replacement, along with albumin and $\alpha-1$-antitrypsin [58]. Apo A1 has also been shown to adsorb to the surface of copolymer nanoparticles from plasma [59].

Several additional proteins were detected at 15.0, 14.1, 13.1. 9.9 and $9.5 \mathrm{kDa}$ and these are tentatively assigned to low abundant proteins hemoglobin $\alpha$-chain $(15,184 \mathrm{Da})$, serum amyloid A (14,516 Da), beta-2-microglobulin $(13,667 \mathrm{Da}), \quad$ alpha 1-antichymotrypsin (Fragment) $(9,794 \mathrm{Da})$, platelet factor $4(9,523 \mathrm{Da})$. Finally, a number of other peaks are present in the spectrum and it is not possible to provide any possible assignments to them (11.9, 8.2, 8.0, 7.7, 7.1, and $6.0 \mathrm{kDa}$ ) based on current knowledge despite there being a large number of possibilities in the protein databases. Handling of serum and its preparation from plasma can change its composition by producing proteolytic fragments of larger protein $[60,61]$.

The coatings produced here were also assessed by surface-MALDI after $1 \mathrm{~h}$ exposure to $10 \%$ FBS. Figure 7 shows the spectrum of the in situ annealed $700^{\circ} \mathrm{C}$ surface and clearly shows a number of similarities to the control
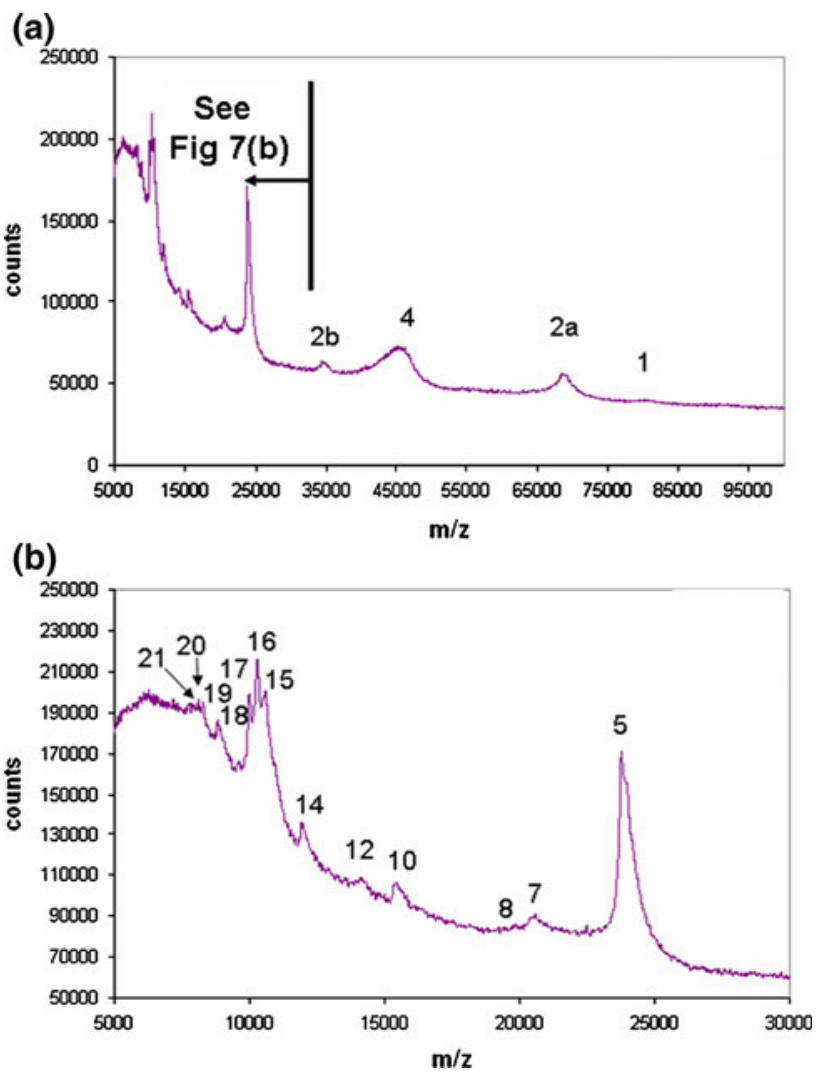

Fig. 7 Surface-MALDI spectrum for the ISA $700^{\circ} \mathrm{C}$ sample (ISAin situ annealed)

surface, however, a number of peaks are not present in the spectrum. Table 8 is a summary of the peaks detected for all the hydrid coatings generated from the surface-MALDI data. The only additional protein detected on any of the surfaces is a low intensity peak at $28.5 \mathrm{kDa}$, which is adsorbed to the in situ annealed $500^{\circ} \mathrm{C}$ surface. This may be apolipoprotein $\mathrm{A} 1$, although the mass is lower than expected for bovine Apo A1 (MW 30,276 Da). The major peaks detected on the control substrate appear on all the hybrid surfaces tested, namely, at $68.3,34.3 \mathrm{kDa}$ (albumin), 38.4-51.0 kDa (haptoglobulin, $\alpha$-1-antitrypsin, $\alpha$-1-antichymotrypsin, beta-2-glycoprotein, alpha-2-hs-glycoprotein, $\alpha-1-1$-microglobulin and inter- $\alpha$-trypsin inhibitor light chain), $23.7 \mathrm{kDa}$ (platelet-derived growth factor beta isoform 1 and Interleukin 6 (IL-6)), $20.3 \mathrm{kDa}$ (fibroblast growth factor 12 isoform 2 or transforming growth factor beta regulator 1), $15.3 \mathrm{kDa}$ (apolipoprotein B100, prealbumin, or hemoglobin beta fetal chain), $10.5 \mathrm{kDa}$ (apolipoprotein A-II), $10.2 \mathrm{kDa}$ (apolipoprotein C-III), $9.9 \mathrm{kDa}$ (Alpha 1-antichymotrypsin (Fragment)), and $8.7 \mathrm{kDa}$ (apolipoprotein C-II). There are also traces of transferrin (79.4), vitamin-d-binding protein, or vitronectin, or alpha1B-glycoprotein, or hemopexin, or antithrombin III, and/or $\alpha-2$ antiplasmin in the mass range $38.4-51.0 \mathrm{kDa}$. In addition, there are clear variations in the relative intensities 
Table 8 Summary of the protein peaks detected on the various $\mathrm{Ca}-\mathrm{P}$ surfaces (ISA-in situ annealed)

\begin{tabular}{|c|c|c|c|c|}
\hline \multirow[t]{2}{*}{ Peak No. } & \multirow{2}{*}{$\begin{array}{l}\text { Detected } \\
\text { MW (kDa) }\end{array}$} & \multicolumn{3}{|l|}{ Surface } \\
\hline & & ISA 500 & ISA 600 & ISA 700 \\
\hline 1 & 79.4 & Trace & Trace & Trace \\
\hline $2 a, 2 b$ & $68.3,34.3$ & Yes & Yes & Yes \\
\hline 3 & $52.7-57.1$ & Trace & Trace & No \\
\hline 4 & $38.4-51.0$ & Yes & Yes & Yes \\
\hline 5 & 23.7 & Yes & Yes & Yes \\
\hline 6 & 23.0 & Yes & No & No \\
\hline 7 & 20.3 & Yes & Trace & Yes \\
\hline 8 & 19.7 & No & No & Trace \\
\hline 9 & 16.3 & Yes & Trace & No \\
\hline 10 & 15.3 & Yes & Yes & Yes \\
\hline 11 & 15.0 & Trace & No & No \\
\hline 12 & 14.1 & Yes & No & Yes \\
\hline 13 & 13.1 & Trace & No & No \\
\hline 14 & 11.9 & No & Yes & Yes \\
\hline 15 & 10.5 & Yes & Yes & Yes \\
\hline 16 & 10.2 & Yes & Yes & Yes \\
\hline 17 & 9.9 & Yes & Yes & Yes \\
\hline 18 & 9.5 & Trace & No & Yes \\
\hline 19 & 8.7 & Yes & Yes & Yes \\
\hline 20 & 8.2 & Trace & Trace & Trace \\
\hline 21 & 8.0 & Trace & Trace & Trace \\
\hline 22 & 7.7 & No & No & No \\
\hline 23 & 7.1 & No & No & No \\
\hline 24 & 6.0 & Trace & No & No \\
\hline
\end{tabular}

of the peaks between samples, which clearly indicate differences in the surface concentrations of each of the species.

What is clear from the surface-MALDI-MS results is that the coatings produced here inhibit the adsorption of a range of specific proteins with molecular weights (MWs) of less than $23.1 \mathrm{kDa}$ more readily than those at higher MWs $(>23.1 \mathrm{kDa})$, as shown in Table 8 . In addition to this, the adsorption of proteins associated with peaks at MWs of between 52.7 and $57.1 \mathrm{kDa}$ are also inhibited in the in situ annealed $700^{\circ} \mathrm{C}$ samples. Furthermore, both the in situ annealed $600^{\circ} \mathrm{C}$ and in situ annealed $700^{\circ} \mathrm{C}$ samples inhibit the adsorption of a greater range of proteins than the in situ annealed $500^{\circ} \mathrm{C}$ samples or the $\mathrm{Ti}-6 \mathrm{Al}-4 \mathrm{~V}$ substrate as shown in Tables 7 and 8. These particular samples show a higher $\mathrm{Ca} / \mathrm{P}$ ratio in the uppermost surface region from the XPS data $\left(75^{\circ} \mathrm{TOA}\right)$ when compared to the in situ annealed $500^{\circ} \mathrm{C}$ samples. Generally, an increase in the $\mathrm{Ca} / \mathrm{P}$ ratio increases the adsorption rate of proteins onto the surface of $\mathrm{Ca}-\mathrm{P}$ materials, however, this phenomenon has been shown to differ greatly depending on the protein in question [62]. These adsorbates were assigned to a combination of growth factors and lipoproteins present in serum.

Direct identification of the proteins/peptides detected on the surfaces, apart from perhaps some of the most concentrated proteins in serum, is not possible on account of the complexity of serum. However, actual detection by surface-MALDI indicates that they are present in significant concentrations at the interface between the implant surface and the cells. Additionally, the data generated highlights the complexity of protein adsorption phenomena when surfaces are exposed to biological fluids such as bovine serum. There are significant differences between all the surfaces in terms of peaks detected, which may translate into differences in cellular responses. In order to determine more precisely the compositions of the protein adlayers and the function of the individual proteins on the hybrid coatings classical proteomics approaches will most likely be needed in combination with experiments involving sera selectively depleted of suspected proteins or sera that have been fractionated, e.g. by dialysis or gel permeation chromatography. Our initial studies most certainly highlight the need for more advanced methods of identifying protein adsorbates on surfaces where proteins are allowed to freely adsorb, and are likely to influence initial cell attachment and growth on biomaterials. Such phenomena are obviously very important but too often overlooked in the biomaterials community.

\section{Conclusions}

A range of different $\mathrm{Ca}-\mathrm{P}$ and $\mathrm{Ca}-\mathrm{P} / \mathrm{TiO}_{2}$ surfaces were produced in this study utilising RF magnetron sputtering. The surfaces, which were produced via an in situ annealing approach during sputter deposition were characterised using surface specific analytical techniques. These analyses highlighted the fact that a hybrid $\mathrm{Ca}-\mathrm{P} / \mathrm{TiO}_{2}$ surface was only produced after in situ annealing to $700^{\circ} \mathrm{C}$, whereas the coatings produced at 500 and $600^{\circ} \mathrm{C}$ displayed the characteristics of a Ca-P surface, most notably at the higher TOA $\left(75^{\circ}\right)$. This study clearly indicates that surfaceMALDI-MS has significant utility as a tool for studying the dynamic nature of protein adsorption onto the surfaces of bioceramic coatings. In addition, differences in the coating properties were seen to have a significant influence on the nature of the protein adsorption. However, due to the complexity of the systems studied here it is recognised that additional studies will have to be undertaken in order to elucidate the exact nature of the protein adsorption observed here. The in vitro cellular responses to these materials in the presence of serum have been started and will be presented in a future manuscript. 
Acknowledgments This work was kindly supported by a RTD Networking grant from Invest Northern Ireland (RTD 375). This work was part of the Centre for Nanostructured Polymer Surfaces for Medical Applications, funded by the Danish Ministry for Science, Technology and Innovation (2002-603-4001-87). The authors would also like to thank Kratos Analytical (UK) for their assistance with the XPS analysis.

\section{References}

1. Wolke JGC, van Dijk K, Schaeken HG, de Groot K, Jansen JA. Evaluation of plasma-spray and magnetron-sputter $\mathrm{Ca}-\mathrm{P}$-coated implants: an in vivo experiment using rabbits. J Biomed Mater Res. 1994;28:1477-84.

2. van Dijk K, Schaeken HG, Wolke JGC, Maree CHM, Habraken FHPM, Verhoeven J, Jansen JA. Enhancing osseointegration using surface-modified titanium implants. J Biomed Mater Res. 1995;29:269-76.

3. van Dijk K, Schaeken HG, Maree CHM, Verhoeven J, Wolke JGC, Habraken FHPM, Jansen JA. Influence of Ar pressure on r.f. magnetron-sputtered $\mathrm{Ca}_{5}\left(\mathrm{PO}_{4}\right)_{3} \mathrm{OH}$ layers. Surf Coat Technol. 1995;76-77:206-10.

4. van Dijk K, Schaeken HG, Wolke JGC, Jansen JA. Influence of annealing temperature on RF magnetron sputtered calcium phosphate coatings. Biomaterials. 1996;17:405-10.

5. van Dijk K, Verhoeven J, Maree CHM, Habraken FHPM, Jansen JA. Study of the influence of oxygen on the composition of thin films obtained by r.f. sputtering from a $\mathrm{Ca}_{5}\left(\mathrm{PO}_{4}\right)_{3} \mathrm{OH}$ target. Thin Solid Films. 1997;304:191-5.

6. Wolke JGC, de Groot K, Jansen JA. Dissolution and adhesion behaviour of radio-frequency magnetron-sputtered $\mathrm{Ca}-\mathrm{P}$ coatings. J Mater Sci. 1998;33:3371-6.

7. Boyd AR, Akay M, Meenan BJ. Influence of target surface degradation on the properties of r.f. magnetron-sputtered calcium phosphate coatings. Surf Int Anal. 2003;35:188-98.

8. Wolke JGC, van der Waerden JPCM, Schaeken HG, Jansen JA. In vivo dissolution behavior of various RF magnetron-sputtered $\mathrm{Ca}-\mathrm{P}$ coatings on roughened titanium implants. Biomaterials. 2003;24:2623-9.

9. Nelea V, Morosanu C, Iliescu M, Mihailescu IN. Microstructure and mechanical properties of hydroxyapatite thin films grown by RF magnetron sputtering. Surf Coat Technol. 2003;173:315-22.

10. Boyd AR, Meenan BJ, Leyland NS. Surface characterisation of the evolving nature of radio frequency $(\mathrm{RF})$ magnetron sputter deposited calcium phosphate thin films after exposure to physiological solution. Surf Coat Technol. 2006;200:6002-13.

11. Meenan BJ, Boyd A, Leyland NS, Love E, Akay M. The influence of substrate morphology on the structure and composition of RF sputter deposited calcium phosphate thin films. Bioceramics. 1999;12:471-4.

12. Lo WJ, Grant DM, Ball MD, Welsh BS, Howdle SM, Antonov EN, Bagratashvili VN, Popov VK. Physical, chemical, and biological characterization of pulsed laser deposited and plasma sputtered hydroxyapatite thin films on titanium alloy. J Biomed Mater Res. 2000;50:536-45.

13. Boyd AR, Duffy H, McCann R, Cairns ML, Meenan BJ. The Influence of argon gas pressure on co-sputtered calcium phosphate thin films. Nucl Instrum Methods Phys Res B. 2007;258: $421-8$.

14. Cairns ML, Meenan BJ, Burke GA, Boyd AR. Effect of nanoscale topography on fibronectin adsorption to sputter deposited calcium phosphate thin films. Int J Nano Biomater. 2008;1: 280-98.
15. Lu Y, Li M, Li S, Wang Z, Zhu R. Plasma-sprayed hydroxyapatite + titania composite bond coat for hydroxyapatite coating on titanium substrate. Biomaterials. 2004;25:4393-403.

16. Li H, Khor KA, Cheang P. Impact formation and microstructure characterization of thermal sprayed hydroxyapatite/titania composite coatings. Biomaterials. 2003;24:949-57.

17. Lin C, Yen S. Characterization and bond strength of electrolytic $\mathrm{HA} / \mathrm{TiO}_{2}$ double layers for orthopedic applications. J Mater Sci Mater Med. 2004;15:1237-46.

18. Wang Y, Li Y, Yu H, Ding J, Tang X, Li J, Zhou Y. In situ fabrication of bioceramic composite coatings by laser cladding. Surf Coat Technol. 2005;200:2080-4.

19. Manso M, Langlet M, Fernandez M, Vasquez L, Martinez-Duart JM. Surface and interface analysis of hydroxyapatite/ $/ \mathrm{TiO}_{2}$ biocompatible structures. Mater Sci Eng C. 2003;23:451-4.

20. Milella E, Conentino F, Licciulli A, Massaro C. Preparation and characterisation of titania/hydroxyapatite composite coatings obtained by sol-gel process. Biomaterials. 2001;22:1425-31.

21. Kumar RR, Wang M. Functionally graded bioactive coatings of hydroxyapatite/titanium oxide composite system. Mater Lett. 2002;55:133-7.

22. Boyd AR, Burke GA, Duffy H, Cairns ML, O'Hare P, Meenan BJ. Characterisation of calcium phosphate/titanium dioxide hybrid coatings. J Mater Sci Mater Med. 2008;19:485-98.

23. Boyd AR, Duffy H, McCann R, Meenan BJ. Sputter deposition of calcium phosphate/titanium dioxide hybrid thin films. Mater Sci Eng C. 2008;28:228-36.

24. Rosengren $\AA$, Pavlovic E, Oscarsson S, Krajewski A, Ravaglioli A, Piancastelli A. Plasma protein adsorption pattern on characterized ceramic biomaterials. Biomaterials. 2002;23:1237-47.

25. Rees SG, Hughes Wassell DT, Shellis RP, Embery G. Effect of serum albumin on glycosaminoglycan inhibition of hydroxyapatite formation. Biomaterials. 2004;25:971-7.

26. Siebers MC, ter Brugge PJ, Walboomers XF, Jansen JA. Integrins as linker proteins between osteoblasts and bone replacing materials. A critical review. Biomaterials. 2005;26:137-46.

27. Sawyer AA, Hennessy KM, Bellis SL. Regulation of mesenchymal stem cell attachment and spreading on hydroxyapatite by RGD peptides and adsorbed serum proteins. Biomaterials. 2005; 26:1467-75.

28. Sawyer AA, Hennessy KM, Bellis SL. The effect of adsorbed serum proteins, RGD and proteoglycan-binding peptides on the adhesion of mesenchymal stem cells to hydroxyapatite. Biomaterials. 2007;28:383-92.

29. Kilpadi KL, Chang P-L, Bellis SL. Hydroxylapatite binds more serum proteins, purified integrins, and osteoblast precursor cells than titanium or steel. J Biomed Mater Res A. 2001;57:258-67.

30. Serro AP, Bastos M, Costa Pessoa J, Saramago B. Bovine serum albumin conformational changes upon adsorption on titania and on hydroxyapatite and their relation with biomineralization. J Biomed Mater Res A. 2004;70A:420-7.

31. Ellingsen JE. A study on the mechanism of protein adsorption to $\mathrm{TiO}_{2}$. Biomaterials. 1991;12:593-6.

32. Yang Y, Glover R, Ong JL. Fibronectin adsorption on titanium surfaces and its effect on osteoblast precursor cell attachment. Colloid Surf B Biointerfaces. 2003;30:291-7.

33. Klinger A, Steinberg D, Kohavi D, Sela MN. Mechanism of adsorption of human albumin to titanium in vitro. $\mathrm{J}$ Biomed Mater Res A. 1997;36:387-92.

34. Yang Y, Cavin R, Ong JL. Protein adsorption on titanium surfaces and their effect on osteoblast attachment. J Biomed Mater Res A. 2003;67A:344-9.

35. Wilson CJ, Clegg RE, Leavesley DI, Pearcy MJ. Mediation of biomaterial-cell interactions by adsorbed proteins: a review. Tissue Eng. 2005;11(1-2):1-18. (and the cited references). 
36. Omenn GS. Exploring the human plasma proteome. Proteomics. 2005;5:3223-5.

37. Anderson NL, Anderson NG. The human plasma proteome: history, character, and diagnostic prospects. Mol Cell Proteomics. 2002;1:845-67.

38. Zheng X, Baker H, Hancock WS, Fawaz F, McCaman M, Pungor E Jr. Proteomic analysis for the assessment of different lots of fetal bovine serum as a raw material for cell culture. Part IV. Application of proteomics to the manufacture of biological drugs. Biotechnol Prog. 2006;22(5):1294-300.

39. Kingshott P, Hoecker H. Adsorption of proteins: assessment methods. In: Somasundaran P, editor. Encyclopedia of surface and colloid science, vol 5. 2st ed. New York: Taylor and Francis; 2006. p. 669-94.

40. Villar-Garea A, Griese M, Imhof A. Biomarker discovery from body fluids using mass spectrometry. J Chromatogr B Anal Technol Biomed Life Sci. 2007;849(1-2):105-14.

41. Zenobi R, Knochenmuss R. Ion formation in MALDI mass spectrometry. Mass Spectrom Rev. 1998;17:337-66.

42. Kingshott P, St John HAW, Chatelier RC, Griesser HJ. SurfaceMALDI mass spectrometry detection of proteins adsorbed in vivo onto contact lenses. J Biomed Mater Res. 2000;49:36-42.

43. Griesser HJ, Kingshott P, McArthur SL, McLean KM, Kinsel GR, Timmons RB. Surface-MALDI mass spectrometry in biomaterials research. Biomaterials. 2004;25:4861-75.

44. Konashi K, Kambara M, Noshi H, Uemura MJ. X-ray photoelectron spectroscopic (ESCA) study on the surface of hydroxyapatite. J Osaka Dent Univ. 1987;21:1-8.

45. Roome CM, Adam CD. Crystallite orientation, anisotropic strains in thermally sprayed hydroxyapatite coatings. Biomaterials. 1995; 16:691-6.

46. Tong W, Chen J, Li X, Feng J, Cao Y, Yang Z, Zhang X. Preferred orientation of plasma sprayed hydroxyapatite coatings. J Mater Sci. 1996;31:3739-42.

47. Jha LJ, Santos JD, Knowles JC. Characterization of apatite layer formation on $\mathrm{P}_{2} \mathrm{O}_{5}-\mathrm{CaO}, \mathrm{P}_{2} \mathrm{O}_{5}-\mathrm{CaO}-\mathrm{Na}_{2} \mathrm{O}$, and $\mathrm{P}_{2} \mathrm{O}_{5}-\mathrm{CaO}-$ $\mathrm{Na}_{2} \mathrm{O}-\mathrm{Al}_{2} \mathrm{O}_{3}$ glass hydroxyapatite composites. J Biomed Mater Res. 1996;31:481-6.

48. Ong JL, Lucas LC, Raikar GN, Weimer JJ, Gregory JC. Surface characterization of ion-beam sputter-deposited Ca-P coatings after in vitro immersion. Colloid Surf A Physiochem Eng Asp. 1994;87:151-62.

49. Long JD, Xu S, Foo HY, Diong CH. Syntheses and properties of bioactive $\mathrm{Ca}-\mathrm{P}-\mathrm{Ti}$ thin films synthesized by reactive plasma cosputtering deposition. Key Eng Mater. 2003;240-242:303-6.

50. Long J, Xu S, Cai JW, Jiang N, Lu JH, Ostrikov KN, Diong CH. Structure, bonding state and in vitro study of $\mathrm{Ca}-\mathrm{P}-\mathrm{Ti}$ film deposited on Ti6Al4V by RF magnetron sputtering. Mater Sci Eng C Biomim Mater Sens Syst. 2002;20:175-80.

51. Lee TM, Chang E, Yang CY. Surface characteristics of Ti6Al4V alloy: effect of materials, passivation and autoclaving. J Mater Sci Mater Med. 1998;9:439-48.

52. Kumar PM, Badrinarayanan S, Sastry M. Nanocrystalline $\mathrm{TiO}_{2}$ studied by optical, FTIR and X-ray photoelectron spectroscopy: correlation to presence of surface states. Thin Solid Films. 2000;358:122-30.

53. Xu S, Long J, Sim L, Diong CH, Ostrikov K (Ken). RF plasma sputtering deposition of hydroxyapatite bioceramics: synthesis, performance, and biocompatibility. Plasma process. Polymer. 2005;2:373-90.

54. Qian WJ, Jacobs JM, Camp DG II, Monroe ME, Moore RJ, Gritsenko MA, Calvano SE, Lowry SF, Xiao W, Moldawer LL, Davis RW, Tompkins RG, Smith RD. Comparative proteome analyses of human plasma following in vivo lipopolysaccharide administration using multidimensional separations coupled with tandem mass spectrometry. Proteomics. 2005;5:572-84.

55. iProClass database. http://pir.georgetown.edu/.

56. Fujita M, Ishihara M, Ono K, Hattori H, Kurita A, Shimizu M, Mitsumaru A, Segawa D, Hinokiyama K, Kusama Y, Kikuchi M, Maehara T. Adsorption of inflammatory cytokines using a heparin-coated extracorporeal circuit. Artif Organs. 2000;26(12): $1020-5$.

57. Yan X, Scherphof GL, Kamps JAAM. Liposome opsonization. J Lipsome Res. 2005;15:109-39.

58. Sun D-H, Trindade CD, Nakashima Y, Maloney WJ, Goodman SB, Schurman DJ, Smith RL. Human serum opsonization of orthopedic biomaterial particles: protein-binding and monocyte/ macrophage. J Biomed Mater Res. 2003;65A:290-8.

59. Cedervall T, Lynch I, Foy M, Berggærd T, Donnelly SC, Cagney G, Linse S, Dawson KA. Detailed identification of plasma proteins adsorbed on copolymer nanoparticles. Angew Chem Int Ed. 2007;46:5754-6.

60. Banks RE, Stanley AJ, Cairns DA, Barrett JH, Clarke P, Thompson D, Selby PJ. Influences of blood sample processing on low-molecular-weight proteome identified by surface-enhanced laser desorption/ionization mass spectrometry. Clin Chem. 2005;51(9):1637-49.

61. Zimmerman LJ, Wernke GR, Caprioli RM, Liebler DC. Identification of protein fragments as pattern features in MALDI-MS analysis of serum. J Proteome Res. 2005;4:1672-80.

62. Kandori K, Tsuyama S, Tanaka H, Ishikawa T. Protein adsorption characteristics of calcium hydroxyapatites modified with pyrophosphoric acids. Colloids Surf B Biointerfaces. 2007;58:98104. 